\title{
Bovine Coronavirus Detection in a Collection of Diarrheic Stool Samples Positive for Group A Bovine Rotavirus
}

\author{
Aline Fernandes Barry, Alice Fernandes Alfieri, Danilo Tancler Stipp and Amauri Alcindo \\ Alfieri $^{*}$ \\ Laboratório de Virologia Animal; Departamento de Medicina Veterinária Preventiva; Universidade Estadual de \\ Londrina; C. P.: 6001; 86051-990; Londrina - PR - Brasil
}

\begin{abstract}
Neonatal diarrhea is an important cause of economic losses for cattle farmers. The main viral etiologies of enteric diseases are group A rotaviruses (GARV) and the bovine coronavirus (BCoV). Although both viruses infect calves of the same age, the occurrence of mixed infections is still under studied. The present study describes the co-infection of BCoV and GARV in stool samples. Forty-four diarrheic fecal samples from calves up to 60 days old that had previously tested positive for GARV by SS-PAGE were analyzed using semi-nested PCR for BCoV. A product with $251 \mathrm{bp}$ of the BCoV nucleoprotein gene was amplified in 15.9\% (7/44) of the samples, demonstrating that coinfection is not an unusual event. These results reinforce the need for testing for both GARV and BCoV, even in fecal samples that previously tested positive for one virus.
\end{abstract}

Key words: calf, diarrhea, BCoV, rotavirus, SN-PCR, co-infection

\section{INTRODUCTION}

Neonatal diarrhea is one of the main causes of calf mortality worldwide. The disease results in major economic losses in many dairy and beef cattle herds that result from treatment costs and calf deaths. Calf diarrhea is considered to be a multifactorial disease. Several environmental, management-related, nutritional, and physiological factors may occur either alone or in synergy with different infectious agents such as protozoans, bacteria, and/or viruses. In calves, bovine group A rotavirus (GARV) and bovine coronavirus (BCoV) are the viruses most commonly associated with neonatal diarrhea and it is not unusual that both viruses can concomitantly infect calves (Snodgrass et al., 1986; Holland, 1990; Alfieri et al., 2006; Oliveira Filho et al., 2007).

Rotaviruses belong to the Reoviridae family. They have icosahedral symmetry and a non-enveloped capsid formed by three concentric layers of protein that is $70-90 \mathrm{~nm}$ in diameter. The rotavirus genome is composed of 11 double-stranded RNA segments (dsRNA). Based on the common group antigen (VP6 protein), rotaviruses are classified antigenically into seven serogroups (A-G). The co-migration of genomic segments 7,8 , and 9 in polyacrylamide gel electrophoresis (PAGE) is an important characteristic of group A rotaviruses (Estes, 1996).

Several techniques have been developed to diagnose bovine GARV by detecting the viral

\footnotetext{
*Author for correspondence: alfieri@uel.br
} 
particle (cell culture, electron microscopy, immune electron microscopy), viral protein (ELISA, latex agglutination, direct immunofluorescence), and viral genome (SS-PAGE, RT-PCR). All of these methods vary in specificity and sensitivity and present both advantages and disadvantages (Alfieri et al., 1996; Markowska-Daniel et al., 1996).

PAGE followed by silver staining (SS-PAGE) is a well-established technique that is often employed for rotavirus detection (Herring et al., 1982; Pereira et al., 1983). It enables the identification of rotavirus groups by analyzing the migration pattern of the 11 segments of dsRNA, and it has all of the characteristics required for large scale use, such as low cost and ease of execution (Markowska-Daniel et al., 1996).

The Coronavirus genus belongs to the Coronaviridae family and is divided into three genetically distinct groups. $\mathrm{BCoV}$ is classified in group 2 and is a pneumoenteric virus that causes diarrhea and respiratory disease in calves and winter dysentery in adult cattle (Takiuchi et al., 2009). The virus has an envelope $120-160 \mathrm{~nm}$ in diameter and a helical nucleocapsid. The genome is a single-stranded, positive-sense RNA molecule of $27-32 \mathrm{~kb}$. The 13 open reading frames (ORFs) of the genome encode five major structural proteins (ICTV dB 2009).

The frequency of $\mathrm{BCoV}$ infection is quite variable between different geographical regions, the production type (dairy or beef herds), and the diagnostic techniques used. In Brazil, only a few studies have evaluated the $\mathrm{BCoV}$ occurrence in stool samples from calves. The rates of infection range from 14 to $39 \%$ (Jerez et al., 2002; Takiuchi et al., 2006; Oliveira Filho et al., 2007; Stipp et al., 2009).

A few different methods exist to show the presence of $\mathrm{BCoV}$ in stool samples, including electron microscopy (EM), isolation in tissue culture, hemagglutination (HA) / inhibition (HI) assay, and ELISA, although most of them are not useful for diagnosis because they are timeconsuming or have low specificity. A reverse transcription-polymerase chain reaction (RT-PCR) for $\mathrm{BCoV}$ detection in calf fecal samples has high sensitivity and specificity compared to other techniques (Cho et al., 2001).

As some infectious agents may act synergistically during infection, the disease may be more severe in mixed than in single infections. The aim of the present study was to evaluate the frequency of $\mathrm{BCoV}$ and bovine GARV co-infection in a collection of diarrheic stool samples from calves that were previously diagnosed with rotaviruses.

\section{MATERIALS AND METHODS}

\section{Stool samples}

Forty-four diarrheic fecal samples that were positive for bovine GARV by the SS-PAGE technique were included in the study. The samples were collected from March to December of 2004 from calves of up to 60 days of age and kept at 4 ${ }^{\circ} \mathrm{C}$. The calves were from beef and dairy cattle herds located in four Brazilian states: Mato Grosso (MT), Minas Gerais (MG), Paraná (PR), and São Paulo (SP).

Fecal suspensions were prepared at 10 to $20 \%$ $(\mathrm{w} / \mathrm{v})$ in $0.01 \mathrm{M}$ phosphate-buffered saline (PBS) $\mathrm{pH} 7.2$, and centrifuged at $3,000 \mathrm{x}$ g for $15 \mathrm{~min}$ at $4{ }^{\circ} \mathrm{C}$. The supernatants were used for RNA extraction.

\section{RNA extraction}

Aliquots $(400 \mu \mathrm{L})$ of the supernatant from the fecal suspension were treated with SDS at a final concentration of $1 \%(\mathrm{v} / \mathrm{v})$ and kept at $56{ }^{\circ} \mathrm{C}$ for 30 min. Thereafter, a combination of the phenol/chloroform/isoamyl alcohol and silica/guanidine isothiocyanate methods was used (Alfieri et al., 2006) to extract the RNA. The RNA was eluted in $50 \mu \mathrm{L}$ of ultra-pure RNase-free DEPC-treated sterile water and used in the seminested PCR (SN-PCR). Sterile water was included as a negative control for the RNA extraction. A cell culture-adapted BCoV Mebus strain was used as positive control in SN-PCR.

\section{Semi-nested PCR assay}

SN-PCR was performed with the primers BCoV1 sense (5'-CGATGAGGCTATTCCGAC-3') and BCoV2 antisense (5'-TGTGGGTGCGAGTTCTGC-3'); the latter was also used for reverse transcription (RT). For the second round of amplification (semi-nested), $\mathrm{BCoV} 3$ sense (5'TTGCTAGTCTTGTTCTGGC-3') and BCoV2 antisense were used. The primer sequences were based on the highly conserved region of the Mebus strain $\mathrm{N}$ gene (GenBank accession number U00735), and the reactions were performed according to Takiuchi et al. (2006). The sizes of the predicted PCR and SN products were 454 and $251 \mathrm{bp}$, respectively. 
The SN-PCR products were analyzed by electrophoresis on a $2 \%$ agarose gel stained with $0.5 \mu \mathrm{g} / \mathrm{mL}$ ethidium bromide and visualized under UV light.

\section{RESULTS AND DISCUSSION}

The SN-PCR amplified the 251 bp BCoV fragment in $15.9 \%$ (7/44) of the stool samples that were positive for bovine GARV, demonstrating that co-infection with the main viral agents of calf diarrhea is not a rare event.

The presence of $\mathrm{BCoV}$ in bovine GARV-positive stool samples has also been described in other Brazilian studies; the number of samples evaluated by these studies was too low to determine whether the rates were similar to the rate presented herein (Table 1) (Jerez et al., 2002; Brandão et al., 2007; Oliveira Filho et al., 2007).

The bovine GARV and $\mathrm{BCoV}$ co-infection in $15.9 \%$ of the calves demonstrates that infection with both viruses is possible and not rare, even though they infect the same portion of the small intestine, i.e. jejunum and ileum, (Carpio et al., 1981; Saif et al., 1986). Although the frequency of bovine GARV (11 to 19.4\%) and BCoV (14 to 39\%) infections in Brazilian cattle herds are high (Jerez et al., 2002; Alfieri et al., 2006; Takiuchi et al., 2006; Oliveira Filho et al., 2007), only a few studies have been conducted to examine mixed infection by these viruses. It is not possible to confirm if the viruses compete, if the presence of one virus limits infection by the other, or if the infection with one virus favors infection by the second as a consequence of a smaller local immune response. Brandão et al. (2007) also detect both GARV and $\mathrm{BCoV}$ viruses, and suggested that there was a synergistic effect between them in a mixed infection. However, simultaneous infection by these viruses is not enough to confirm that they act in a synergistic way. Such an interaction should be more accurately measured under experimental conditions and not in field observations.

Table 1 - Comparative analysis of bovine coronavirus (BCoV) and bovine group A rotavirus (GARV) mixed infection in calves fecal samples from Brazilian beef and dairy cattle herds.

\begin{tabular}{ccc}
\hline GARV positive samples & Mixed infection (GARV and BCoV) & Study \\
\hline 44 & 7 & This study \\
10 & 2 & Jerez et al., 2002 \\
6 & 1 & Brandão et al., 2007 \\
11 & 2 & Oliveira Filho et al., 2007 \\
\hline
\end{tabular}

Another important result of mixed infection may be related to virus shedding. The calves with mixed infections were more exposed to enteric pathogens, which could lead to a more severe outcome of the infection. Consequently, the recovery from intestinal injury could also be more difficult, resulting in a longer time to recover the intestinal villous. As a consequence, these calves may shed the viruses at higher titers than calves with a single infection. Since the viral load is higher, the onset of the diarrhea would also be earlier.

Outbreaks of diarrhea in calves are frequently associated with bovine GARV infection. It is unusual to perform diagnostic assays for $\mathrm{BCoV}$ in samples that previously tested positive to bovine GARV. Therefore, it is impossible to ascertain if the severity of some bovine GARV diarrhea outbreaks is higher due to a more pathogenic virus strain or mixed infection. Co-infections may also explain some cases of bovine GARV outbreaks in vaccinated populations of calves (Barreiros et al., 2004). The presence of $\mathrm{BCoV}$ might decrease the intestinal immunity and make rotavirus infection easier, even with virus strains that are not usually associated with high pathogenicity.

In Brazil, the available calf diarrhea vaccines include inactivated bovine GARV and $\mathrm{BCoV}$ strains and vaccinated herds are protected from diarrhea caused by both viruses and even some bacteria, which are often included in the vaccines. Herd vaccination aims to prevent clinical signs of infection by these enteric pathogens, and it is difficult to determine which viral pathogen is more prevalent in vaccinated herds. It is also unknown if the vaccine-induced immune response is maintained in mixed infections. However, prophylactic vaccination against neonatal calf diarrhea in Brazilian dairy and beef cattle herds is still not used in large scale. 
In conclusion, the detection of $\mathrm{BCoV}$ in fecal samples positive for bovine GARV demonstrates that mixed infection by both viruses is relatively frequent in calves. Considering the high rate of diagnosis in outbreaks of neonatal calf diarrhea, all diarrheic stool samples screened for enteric pathogens must be tested for $\mathrm{BCoV}$, and this is particularly important for stool samples positive for other viruses, such as bovine GARV. This strategy will shed new light on the causes of calf diarrhea outbreaks involving vaccinated beef and dairy cattle herds and outbreaks with severe clinical signs and higher morbidity and mortality rates.

\section{ACKNOWLEDGEMENTS}

The financial resources for the conduction of this study were supported by the project BioAgroPar financed by FINEP, SETI/PR, and Fundação Araucária/PR; and by $\mathrm{CNPq} / \mathrm{Brazil}$. Part of the research activities of this study was carried out in the Agricultural Research Support Laboratory (Laboratório de Apoio à Pesquisa Agropecuária LAPA) / PROPPG / UEL. Alfieri, A.A. and Alfieri, A.F. are recipients of $\mathrm{CNPq}$ fellowships.

\section{RESUMO}

A diarreia neonatal é uma importante causa de perdas econômicas para a criação de bovinos. Os principais agentes etiológicos virais das doenças entéricas são o rotavírus bovino grupo A (GARV) e o coronavírus bovino (BCoV). Embora ambos os vírus infectem bezerros na mesma faixa etária, infecções mistas ainda são pouco estudadas. O presente trabalho descreve a identificação do BCoV em amostras de fezes positivas para o GARV, caracterizando a ocorrência de infecções mistas. Quarenta e quatro amostras de fezes diarreicas de bezerros com até 60 dias de idade, previamente identificadas como positivas para o GARV bovino por meio da técnica de SS-PAGE, foram avaliadas quanto a presença do $\mathrm{BCoV}$ pela técnica de semi-nested PCR. Um produto com 251 $\mathrm{pb}$ do gene da nucleoproteína do $\mathrm{BCoV}$ foi amplificado em 15,9\% (7/44) das amostras de fezes demonstrando que a co-infecção não é um evento raro. Esse resultado enfatizada a importância da realização simultânea do diagnóstico para esses dois importantes vírus entéricos de bezerros em surtos de diarreia neonatal tanto em rebanhos bovinos leiteiros quanto de corte.

\section{REFERENCES}

Alfieri, A. A., Leite, J. P. G., Nakagomi, O., Kaga, E., Woods, P. A., Glass, R. I., Gentsch, J. R. (1996), Characterization of human rotavirus genotype P[8],G5 from Brazil by probe-hybridization and sequence. Arch Virol, 141, 2353-2364

Alfieri, A. A., Parazzi, M. E., Takiuchi, E., Médici, K. C., Alfieri, A. F. (2006), Frequency of group A rotavirus in diarrhoeic calves in Brazilian cattle herds, 1998-2002. Trop Anim Health Prod, 38, 521-526

Barreiros, M. A. B., Alfieri, A. F., Médici, K. C., Leite, J. P. L., Alfieri, A. A. (2004), G and P Genotypes of Group A Rotavirus from Diarrhoeic Calves Born to Cows Vaccinated against the NCDV (P[1],G6) Rotavirus Strain. J Vet Med B Infect Dis Vet Public Health, 51, 104-109

Brandão, P. E., Villarreal, L. Y. B., Souza, S. L. P., Richtzenhain, L. J., Jerez, J. A. (2007), Mixed infections by bovine coronavirus, rotavirus and Cryptosporidium parvum in an outbreak of neonatal diarrhea in beef cattle. Arq Inst Biol, 74, 33-34

Carpio, M., Bellamy, J. E. C., Babiuk, L. A. (1981), Comparative Virulence of Different Bovine Rotavirus Isolates. Can J Comp Med Vet Sci, 45, 38-42

Cho, K. O., Hasoksuz, M., Nielsen, P. R., Chang, K. O., Lathrop, S., Saif, L. J. (2001), Cross-protection studies between respiratory and calf diarrhea and winter dysentery coronavirus strains in calves and RT-PCR and nested PCR for their detection. Arch Virol, 146, 2401-2419

Estes, M. (1996), Rotaviruses and their replication. InFields Virology, 3ed. Raven Press, New York, pp.1625-1655

Herring, A. J., Inglis, N. F., Ojeh, C. K., Snodgrass, D. R., Menzies, J. D. (1982), Rapid diagnosis of rotavirus infection by direct detection of viral nucleic acid in silver-stained polyacrylamide gels. J Clin Microbiol, 16, 473-477

Holland, R. E. (1990), Some infectious causes of diarrhea in young farm animals. Clin Microbiol Rev, 3, 345-375

ICTVdB - The Universal Virus Database, version 4. <http://www.ncbi.nlm.nih.gov/ICTVdb/ICTVdb/>. Access in: 10 jan. 2009.

Jerez, J. A., Brandão, P. E., Buzinaro, M. G., Gregori, F., Rosales, C. A. R., Ito, F. H., Sakai, T. (2002), Detecção de rotavírus e coronavírus em fezes de bezerros neonatos com diarréia criados em vários municípios do estado de São Paulo, Brasil. Arq Inst Biol, 69, 19-23 
Markowska-Daniel, I., Winiarczyk, S., Gradzki, Z., Pejsak, Z. (1996), Evaluation of different methods (ELISA, IF, EM, PAGE) for the diagnosis of rotavirus infection in piglets. Comp Immunol Microbiol Infect Dis, 19, 219-232

Oliveira Filho, J. P., Silva, D. P. G., Pacheco, M. D., Mascarini, L. M., Ribeiro, M. G., Alfieri, A. A., Alfieri, A. F., Stipp, D. T., Barros, B. J. P., Borges, A. S. (2007), Diarrhea in Nelore calves: Clinical and etiologic study. Braz J Vet Res, 27, 419-424

Pereira, H. G., Azeredo, R. S., Leite, J. P. G., Candeias, J. A. N., Racz, M. L., Linhares, A. C., Gabbay, Y. B., Trabulsi, J. R. (1983), Electrophoretic study of the genome of human rotaviruses from Rio de Janeiro, São Paulo, and Belem, Brazil. J Hyg, 90, 117-125

Saif, L. J., Redman, D. R., Theil, K. W. (1986), Experimental coronavirus infection in calves: viral replication in the respiratory and intestinal tracts, $A m$ $J$ Vet Res, 47, 1426-1432

Snodgrass, D. R., Terzolo, H. R., Sherwood, D., Campbell, I., Menzies, J. D., Synge, B. A. (1986), Aetiology of diarrhoea in young calves. Vet Rec, 119, 31-34
Stipp, D. T., Barry, A. F., Alfieri, A. F., Takiuchi, E., Amude, A. M., Alfieri, A. A. (2009), Frequency of $\mathrm{BCoV}$ detection by a semi-nested PCR assay in faeces of calves from Brazilian cattle herds. Trop Anim Health Prod, in press. doi: 10.1007/s11250009-9347-2

Takiuchi, E., Stipp, D. T., Alfieri, A. F., Alfieri A. A. (2006), Improved detection of bovine coronavirus $\mathrm{N}$ gene in faeces of calves infected naturally by a seminested PCR assay and an internal control. J Virol Methods, 131, 148-154

Takiuchi, E., Barry, A. F., Alfieri, A. F., Filippsen, P., Alfieri, A. A. (2009), An Outbreak of Winter Dysentery Caused by Bovine Coronavirus in a HighProduction Dairy Cattle Herd from a Tropical Country. Braz Arch Biol Technol, in press 
PAGINA EM

BRANCO 